\title{
Co-occurrence of Neusticosaurus edwardsii and N. peyeri (Reptilia) in the Lower Meride Limestone (Middle Triassic, Monte San Giorgio)
}

\author{
Rudolf Stockar $\cdot$ Silvio Renesto
}

Received: 4 March 2010/Accepted: 7 February 2011/Published online: 12 November 2011

(C) Swiss Geological Society 2011

\begin{abstract}
A newly opened excavation in the Cassina beds of the Lower Meride Limestone (Monte San Giorgio UNESCO World Heritage List, Canton Ticino, Switzerland), has yielded a pachypleurosaurid (Reptilia: Sauropterygia) specimen which is identified as Neusticosaurus peyeri. The resulting co-occurrence of $N$. peyeri and $N$. edwardsii, the latter so far regarded as the sole species of the genus present in this horizon, challenges the hypothesis of a single anagenetic lineage in Neusticosaurus species from Monte San Giorgio. In addition, it leads to a reconsideration of the phylogenetic inferences about Neusticosaurus evolution in the Monte San Giorgio area. The stratigraphic distribution of the Neusticosaurus species in the Monte San Giorgio basin is updated on the basis of recent finds.
\end{abstract}

Keywords Neusticosaurus - Lower Meride Limestone · Monte San Giorgio · Middle Triassic · Biostratigraphy . Phylogeny

\section{Institutional abbreviations}

MCSN Museo Cantonale di Storia Naturale, Lugano, Switzerland

Editorial handling: Jean-Paul Billon-Bruyat.

R. Stockar $(\bowtie)$

Museo Cantonale di Storia Naturale, Viale Cattaneo 4, 6900 Lugano, Switzerland

e-mail: rudolf.stockar@ti.ch

R. Stockar

Institut de Géologie et Paléontologie, Université de Lausanne,

Anthropole, 1015 Lausanne, Switzerland

S. Renesto

Department of Structural and Functional Biology, Università degli Studi dell'Insubria, via Dunant 3, 21100 Varese, Italy
PIMUZ Paläontologisches Institut und Museum der Universität Zürich, Switzerland

MUMSG Museo del Monte San Giorgio, Meride, Switzerland

\section{Introduction}

The Cassina (also known as "alla Cascina") beds belong to the world-renowned fossiliferous levels of the Middle Triassic Monte San Giorgio Lagerstätte (UNESCO World Heritage List, Canton Ticino, Southern Alps; Fig. 1), particularly famous for its rich and diverse fauna of Middle Triassic marine vertebrates (e.g. Kuhn-Schnyder 1974; Bürgin et al. 1989).

In 2006 a new excavation (Fig. 1) was started by the Museo Cantonale di Storia Naturale (MCSN), Lugano in this fossiliferous horizon, first discovered in 1933 by the University of Zurich which carried out several subsequent excavations in 1937, between 1971 and 1973, and again in 1975 (see Stockar 2010 for a review). The aim of the ongoing excavation is to carefully re-document the level in order to provide a better characterization of the basin. Besides over three hundred fish specimens, a new pachypleurosaurid (Reptilia, Sauropterygia) specimen of the genus Neusticosaurus was found, which is described and discussed below.

\section{Geological setting}

The Middle Triassic succession at Monte San Giorgio (Figs. 1, 2) starts with a fluvio-deltaic sequence dated to the late Anisian (Bellano Formation, Illyrian; Sommaruga 
Fig. 1 Map of the Monte San Giorgio area showing the Middle Triassic carbonate sequence and the location of the excavation site of the Cassina beds near Cassina (after Stockar 2010). Scale bar $1 \mathrm{~km}$

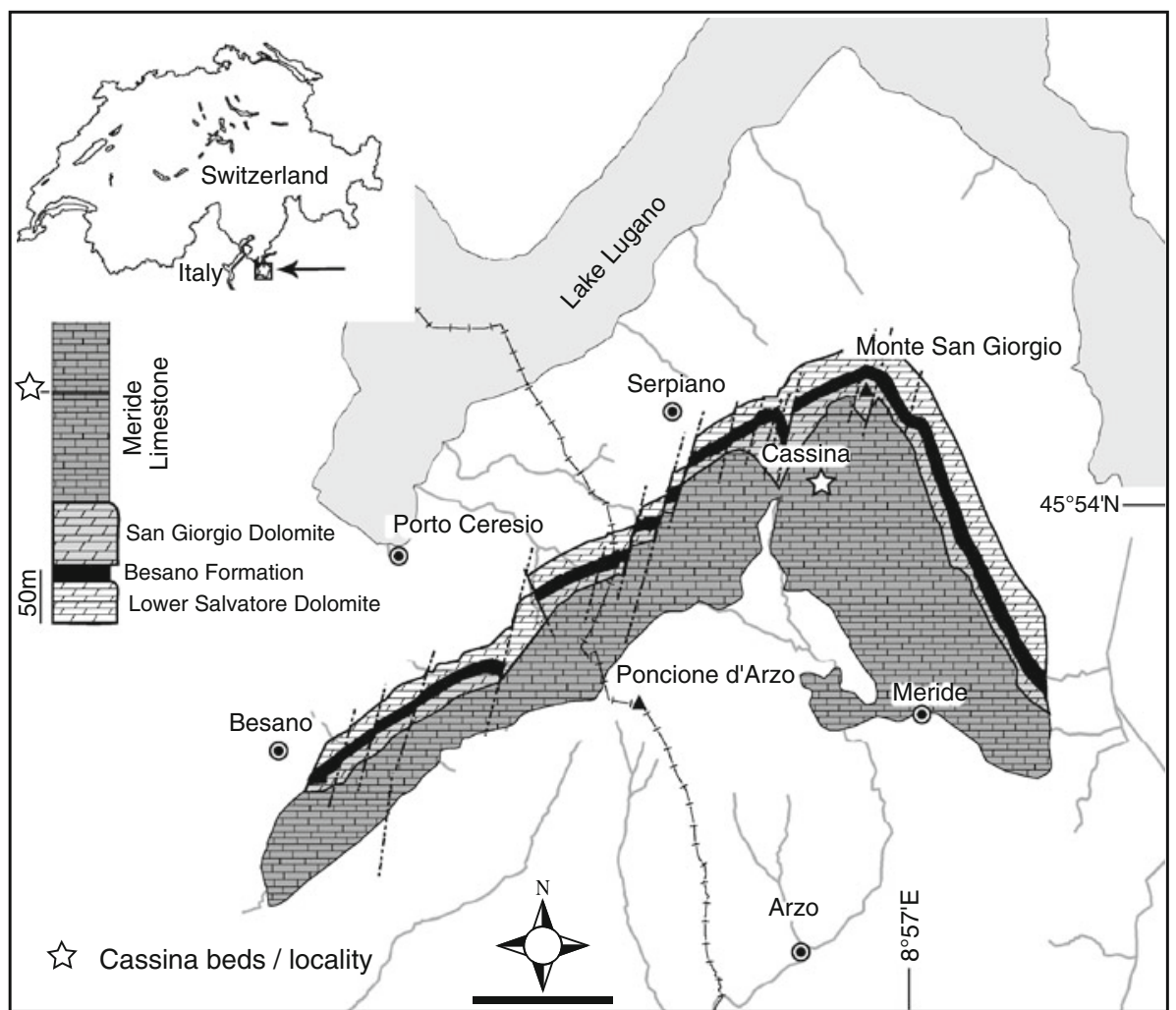

et al. 1997), overlying a Permian volcanic succession. The upper Anisian sediments testify to the progressive transgression of a shallow epicontinental sea and the related growth of carbonate platforms (Salvatore Dolomite; Zorn 1971) north of a land area buried today under the Po Plain (Brusca et al. 1981; Picotti et al. 2007). During the latest Anisian and Ladinian, whereas in the north shallow-water sedimentation continued, in the Monte San Giorgio area the formation of a 30-100 m deep and 10-20 km wide intraplatform basin with restricted circulation (Furrer 1995) resulted in the deposition of the Besano Formation, the San Giorgio Dolomite and the Meride Limestone.

The Besano Formation ("Grenzbitumenzone"; Frauenfelder 1916), is an alternation of black shales and dolomites up to $16 \mathrm{~m}$ thick, including in its uppermost part the Anisian-Ladinian boundary (Brack et al. 2005); a volcanic ash layer lying a few metres below this boundary resulted in an $\mathrm{U}-\mathrm{Pb}$ minimum age of $242.1 \pm 0.6 \mathrm{Ma}$ (Mundil et al. 2010). The Besano Formation, which yielded most of the spectacular vertebrate fossils (fishes and reptiles) together with important index fossils such as ammonoids and daonellid bivalves, grades upwards into the $60 \mathrm{~m}$ thick San Giorgio Dolomite. The overlying 400-600 m thick Meride Limestone (Furrer 1995) begins with the Lower Meride Limestone, $90 \mathrm{~m}$ (Wirz 1945) to $150 \mathrm{~m}$ thick (Furrer 1995), which bears three fossil tetrapod beds (Cava inferiore, Cava superiore and Cassina beds), each yielding different vertebrate assemblages (Sander 1989; Bürgin et al. 1989) and consisting of finely laminated limestones with intercalated volcanic ash layers.

The top of the Lower Meride Limestone is defined by a dolomite bed ("Dolomitband"; Frauenfelder 1916), reaching a thickness of about $30 \mathrm{~m}$ (Wirz 1945). The overlying Upper Meride Limestone is made up of alternating wellbedded limestones and marlstones with an increasing clay content towards the top, where strong seasonal variations of salinity and water level together with the influence from a neighbouring emerged area are documented. The uppermost part comprises the so-called "Kalkschieferzone", which is $120 \mathrm{~m}$ thick and which represents the late evolution of the intraplatform basin, followed by the Carnian regressive phase (Pizzella Marls; Furrer 1995).

\section{The pachypleurosaurids from Monte San Giorgio}

Pachypleurosaurids (Sauropterygia) are generally small Middle Triassic marine reptiles, restricted to shallow-water habitats and widely reported from western Tethyan and eastern Tethyan faunal provinces. According to Rieppel (2000), the family Pachypleurosauridae NopCsA 1928 constitutes a monophyletic taxon. Pachypleurosaurid genera from China (Keichousaurus, Hanosaurus) are the sister-taxa of European pachypleurosaurids (Rieppel 1998, 2000, but 


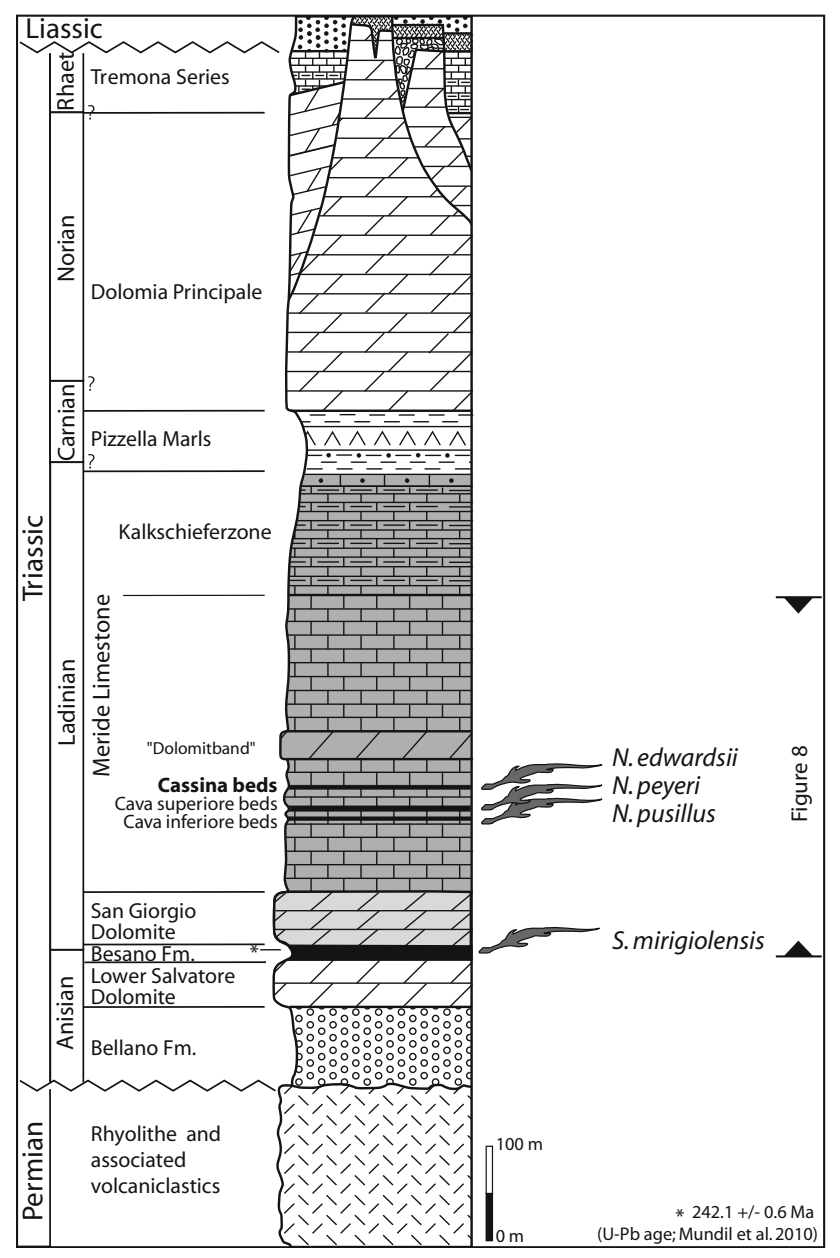

Fig. 2 Stratigraphic distribution of the pachypleurosaurids from Monte San Giorgio, according to Sander (1989) and O'Keefe and Sander (1999). Stratigraphic log modified from Furrer (1995)

Holmes et al. 2008 suggested that Keichousaurus is instead a basal nothosauroid); amongst the latter, the central European Muschelkalk (Germanic Triassic) pachypleurosaurids (Anarosaurus, Dactylosaurus) are the sister-taxa of those from the Alpine Triassic. Cladistic relationships thus indicate a diversification from the eastern Tethyan faunal province into the western Tethys (Rieppel 2000, 2010). The first diversification of pachypleurosaurids in the western Tethyan realm followed the marine transgression that began in the late Early Triassic and proceeded from east to west across central Europe. This enabled the colonization of the central European Muschelkalk basin by pachypleurosaurids (and by other sauropterygians and protorosaurs) from the eastern Tethyan faunal province via the East Carpathian gate following the northern Paleotethys branch (Rieppel and Hagdorn 1997; Rieppel 2010). The opening of southern gateways (the Silesian-Moravian gate in the east and, above all, subsequently by the late Anisian and early Ladinian the Burgundy gate in the west) allowed pachypleurosaurids to disperse into the southern Alpine intraplatform basins
(Rieppel and Hagdorn 1997; Rieppel 2010), where the crown-group pachypleurosaurs (Serpianosaurus-Neusticosaurus clade) further diversified. Admittedly, some isolated remains from the middle Muschelkalk might be referred to Serpianosaurus, but conclusive diagnostic remains are missing (Rieppel and Hagdorn 1997). The increased taxic diversity observed in Monte San Giorgio deposits might be correlated with a greater habitat fragmentation in the intraplatform southern Alpine basin facies, which from the late Anisian is included in the "unstable shelf area" (Mostler 1993), compared to the habitat of the Muschelkalk basin (Rieppel and Lin 1995).

The Alpine pachypleurosaurid genera Serpianosaurus and Neusticosaurus occur in the Monte San Giorgio sequence as abundant vertebrate fossils in the Besano Formation and in all three tetrapod-bearing beds of the Lower Meride Limestone (e.g. Cornalia 1854; Zangerl 1935; Sander 1989). According to Rieppel and Lin (1995), Serpianosaurus RIEPPEL 1989 is the sister-taxon of the genus Neusticosaurus SEeley 1882. In his monographic description, Sander (1989) stated that, at Monte San Giorgio, four species occur in stratigraphic superimposition (Fig. 2), namely, Serpianosaurus mirigiolensis RIEPPEL 1989 (Besano Formation, Anisian-Ladinian boundary) followed through the Ladinian by Neusticosaurus pusillus SeEley 1882 (Cava inferiore beds), Neusticosaurus peyeri SANDER 1989 (Cava superiore beds) and, finally, Neusticosaurus edwardsii Cornalia 1854 (Cassina beds), the latter being the largest species, reaching $120 \mathrm{~cm}$ in length. According to the same author, different species have never been found together in the same horizon, suggesting that their stratigraphic ranges never overlap; consequently, he interpreted the genus Neusticosaurus not only as forming a monophyletic taxon but also as possibly constituting a single lineage undergoing anagenetic change within the Monte San Giorgio sequence. Sander's assumptions were challenged by Kuhn-Schnyder (1994), but the treatment of the three Neusticosaurus species as segments of an anagenetic lineage has subsequently been supported by O'Keefe and Sander (1999). The implications of these conclusions are discussed in Rieppel (2000, p. 52). Even from a not strictly palaeontological point of view, the assumption of a sequential temporal appearance such as this, ruling out species co-occurrence, is particularly intriguing, since it lends a biostratigraphic potential to these commonly occurring tetrapods, even though limited to the Monte San Giorgio where both $N$. peyeri and $N$. edwardsii are found to be endemic. Elsewhere, N. pusillus seems to have persisted virtually without morphological change throughout the late Ladinian in both the Alpine and Germanic Triassic (O'Keefe and Sander 1999; Rieppel 2000). In the Germanic Triassic $N$. pusillus is the only diagnosable Neusticosaurus species (Rieppel and Hagdorn 1997) and 
occurs in the Hohenecker Limestone, a lateral equivalent of the "Lingula Beds" of the upper part of Lower Keuper. According to Brack et al. (1999), this time interval is possibly somewhat younger than the Protrachyceras gredleri ammonoid zone to which, in turn, occurrences of N. pusillus from Monte San Giorgio (Cava inferiore beds) are restricted (Stockar 2010, p. 105), being later substituted by those of $N$. peyeri and $N$. edwardsii (at least in part still within the $P$. gredleri zone; Stockar 2010, p. 105). If correct, the geographic and temporal distribution pattern of $N$. pusillus described above would support the view of Rieppel and Hagdorn (1997), according to which the Serpianosaurus-Neusticosaurus clade diversified in the southern Alpine intraplatform basin facies and later (N. pusillus) returned to the Germanic basin during the Ladinian via the Burgundy gate. However, caution is necessary. As admitted by Rieppel and Lin (1995), unequivocal identification of Neusticosaurus species depends on the availability of fairly complete specimens, which is not usually the case as far as the upper Muschelkalk facies of the Germanic basin is concerned, even though disarticulated pachypleurosaur remains are abundant there. Consequently, the opposite scenario of an initial migration of $N$. pusillus during the early Ladinian from the Germanic to the Alpine basin, where the genus subsequently further diversified, cannot be ruled out a priori.

\section{Materials and methods}

The new excavation site lies to the south of the summit of Monte San Giorgio, a little way out of the outcrop where the Cassina beds were originally discovered in 1933 (Fig. 1). Here, the Cassina beds (Stockar 2010) form an almost $3 \mathrm{~m}$ thick interval, mainly consisting of interbedded, finely laminated, organic-rich shales and limestones (laminite lithofacies) with intercalated thicker limestones (turbidite lithofacies) and volcaniclastic layers derived from volcanic ash suspension-fall (tephra lithofacies). The sequence grades upwards into the thick-bedded dolomitic limestones and dolomites belonging to the "Dolomitband".

So far, the upper third of the succession (Fig. 3) has been excavated bed by bed over a surface of around $40 \mathrm{~m}^{2}$, yielding a well-preserved vertebrate fauna mainly composed of fishes belonging to at least six species, dominated by the large predatory actinopterygian Saurichthys. Reptiles turned out to be rare in the upper part of the Cassina beds and the specimen belonging to the genus Neusticosaurus described here is the only articulated find recovered so far.

The Cassina beds are traditionally regarded as early Ladinian in age (e.g. Hellmann and Lippolt 1981; O'Keefe et al. 1999) but reliable index fossils such as ammonoids and conodonts have never been reported from this horizon.
Furrer et al. (2008) tentatively correlated the Cassina beds with the lowermost Wengen Formation of the GSSP section at Bagolino (Protrachyceras archelaus ammonoid zone, late Ladinian; Brack et al. 2005). This correlation is consistent with the occurrence of Echinitosporites iliacoides (Scheuring 1978), a palynomorph which is regarded as limited to the late Ladinian $P$. archelaus zone (see Stockar 2010 for a review of biostratigraphic data).

The Neusticosaurus specimen is mostly articulated and exposed in ventral view, as reported for most pachypleurosaurids from Cava inferiore and Cava superiore beds. This preservation pattern is ascribed to the development of decay gas in the wide abdominal cavity which held the body with the ventral side upward (Furrer 2003). The specimen was recovered from a $8 \mathrm{~mm}$ thick bed belonging to the laminite lithofacies which, according to Stockar (2010), testifies to anoxic to suboxic bottom-water conditions with possible growth of benthic microbial mats and consequent bio-armouring effect of carcasses.

According to our examination of the historical collection stored at the Paläontologisches Institut und Museum der Universität Zürich (PIMUZ) and to unpublished field data (both courtesy Heinz Furrer, PIMUZ), the bulk of Neusticosaurus material from the Cassina beds comes from just the base of the sequence, which lies approximately $2 \mathrm{~m}$ below the bed bearing the specimen described here. Consequently, the latter is slightly younger than most (if not all) known pachypleurosaurid specimens from the Cassina beds.

The specimen was mechanically prepared with the aid of vibrotools and sharpened needles.

\section{Systematic palaeontology}

\section{Class Reptilia LAURENTI 1768}

Superorder Sauropterygia Owen 1860

Order Eosauropterygia RIEPPEL 1994

Infraorder Pachypleurosauroidea HuENE 1956

Family Pachypleurosauridae NoPCSA 1928

Genus Neusticosaurus SEeley 1882

Neusticosaurus peyeri SANDER 1989

Type species: PIMUZ T3615 (Sander 1989), a complete specimen from Cava superiore beds.

See Sander (1989, p. 601-602) for synonymy.

Material: specimen MCSN 8076 of the collection of the Museo Cantonale di Storia Naturale, Lugano, Switzerland, collected from bed 34, Cassina beds, Lower Meride Limestone (Figs. 4, 5, 6, 7).

Measurements (in $\mathrm{mm}$ ):

Skull length (from the tip of the snout to the occipital condyle): 22.3 
Fig. 3 Detailed

sedimentological log of the upper part of the Cassina beds being investigated, with an indication of the distribution and abundance of vertebrate fossils (after Stockar 2010, modified)

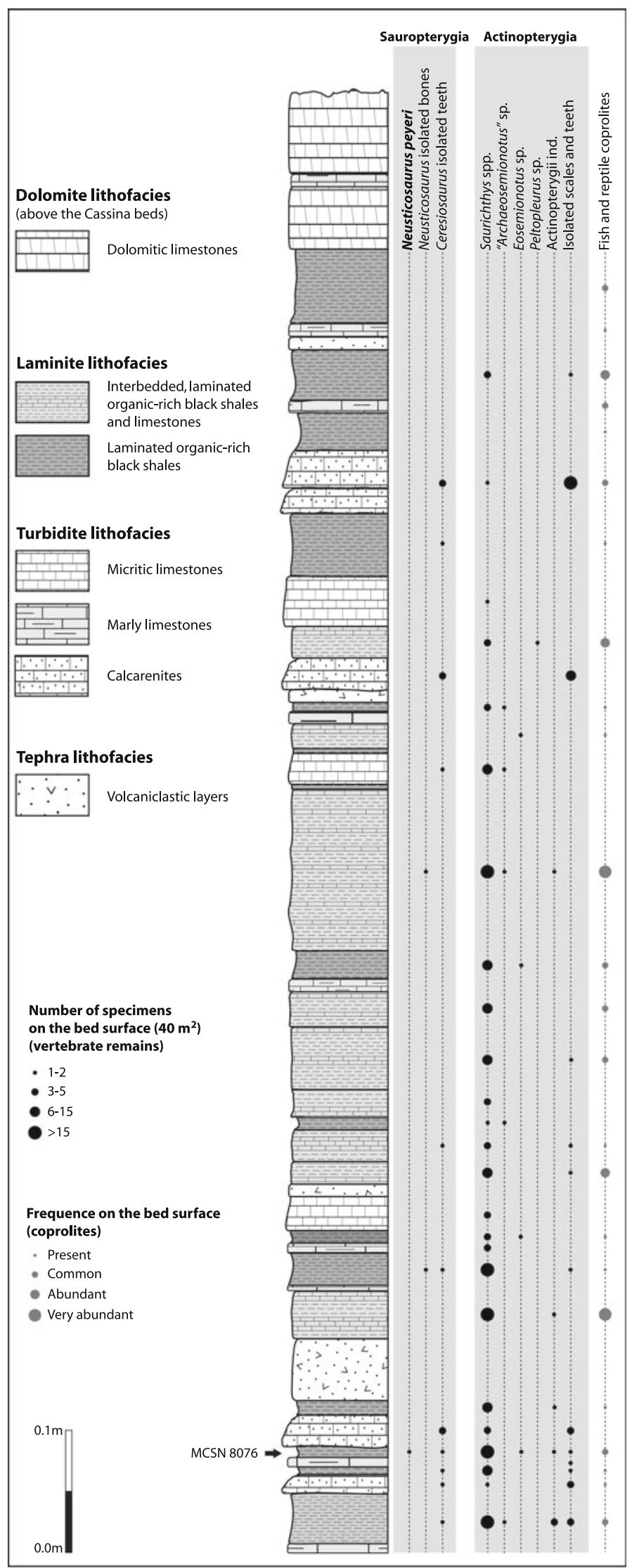


Fig. 4 Neusticosaurus peyeri, specimen MCSN 8076, from the Cassina beds, Lower Meride Limestone (Middle Triassic, Monte San Giorgio).

Photograph of the skeleton in ventral view. Scale bar $10 \mathrm{~mm}$

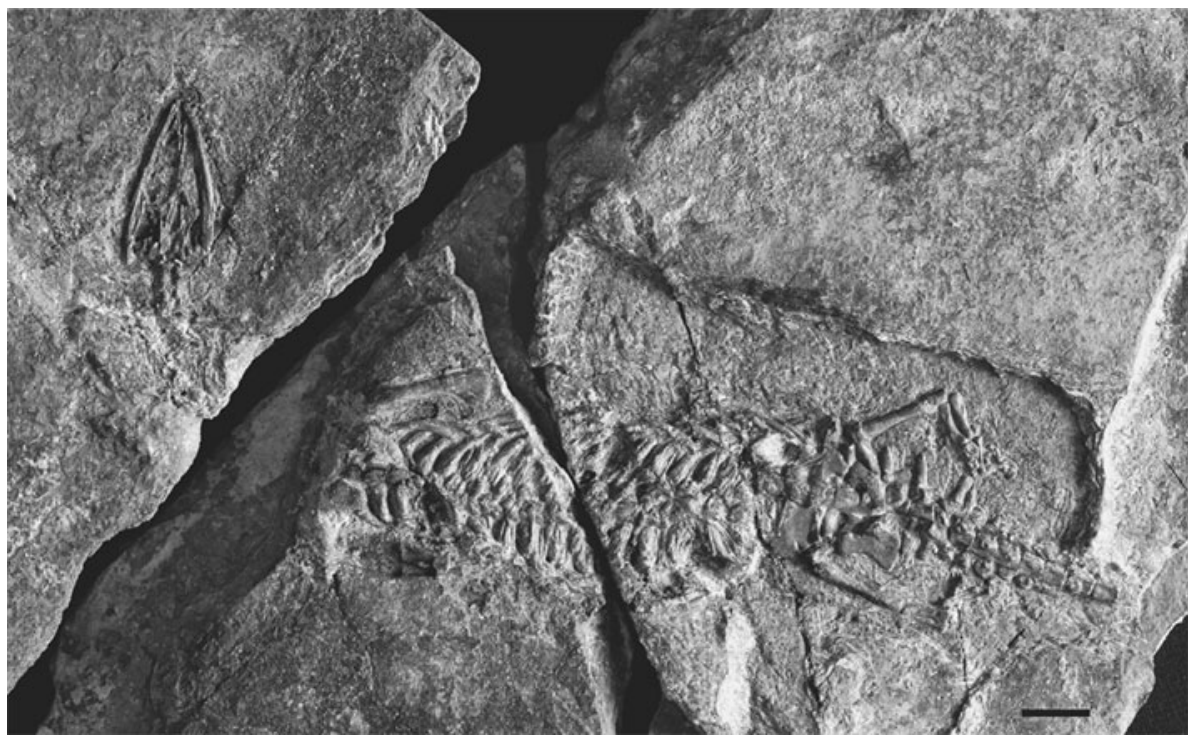

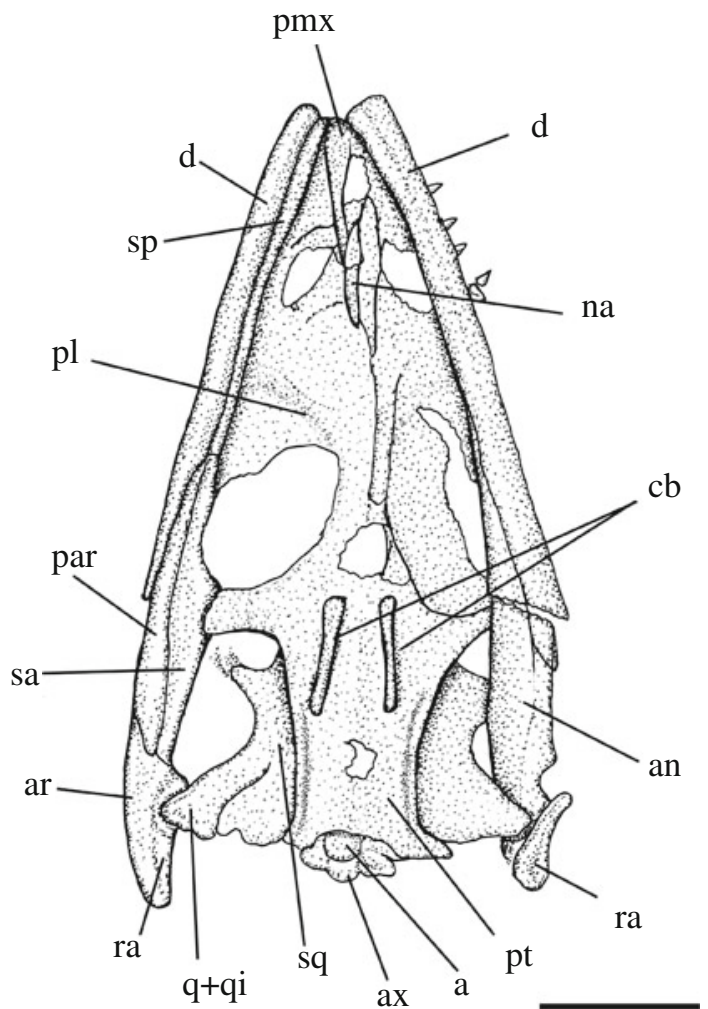

Fig. 5 MCSN 8076, drawing of the skull in ventral view. $a$ atlas, an angular, $a r$ articular, $a x$ axis, $c b$ ceratobranchial, $d$ dentary, na nasal, $p l$ palatine, $p m x$ premaxilla, par prearticular, $p t$ pterygoid, $q+q j$ quadrate and quadratojugal, $r a$ retroarticular, $s a$ surangular, $s p$ splenial, $s q$ squamosal. Scale bar $5 \mathrm{~mm}$

Skull length (from the tip of the snout to the retroarticular process): 25.0

Standard length: 14.7

Humerus: 17.7 (left)

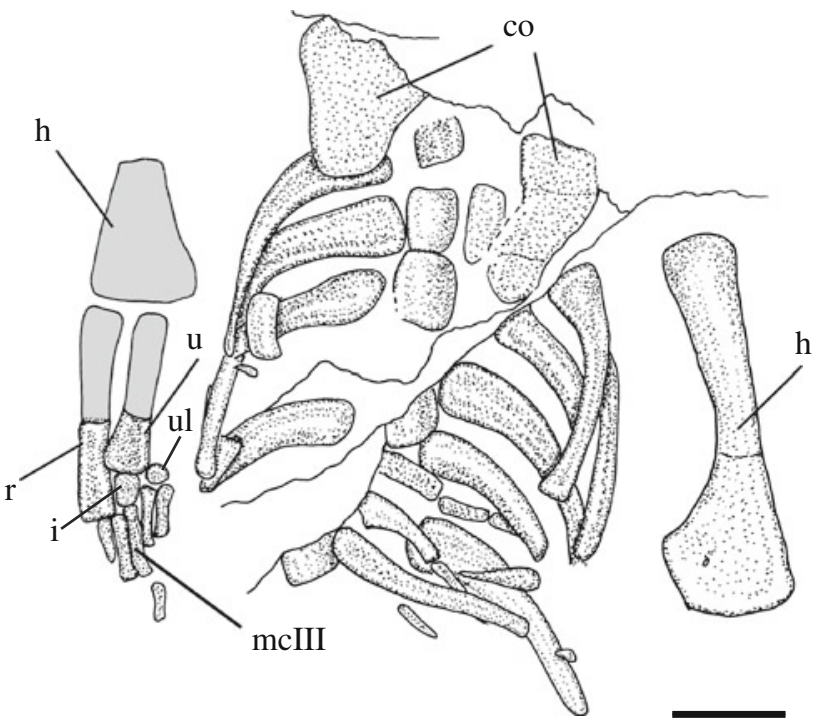

Fig. 6 MCSN 8076, drawing of the pectoral girdle, anterior trunk and forelimbs in ventral view. co coracoid, $h$ humerus, $i$ intermedium, $m c I I I$ third metacarpal, $r$ radius, $u$ ulna, $u l$ ulnare. Scale bar $5 \mathrm{~mm}$

\section{Radius: 9.2 (right)}

Ulna: 7.2 (right)

Femur: 15.0 (left), 14.8 (right)

Fibula: 6.9 (left), 6.8 (right)

\section{Description}

General (Fig. 4). The specimen is exposed in ventral view. It is preserved on several different slabs, dislocated and crossed by faults. As a consequence, different portions of the skeleton are shifted reciprocally and some bones are either missing or poorly preserved; in particular, most of the neck and shoulder girdle, the cranialmost dorsal 
Fig. 7 MCSN 8076, drawing of the sacral and caudal region of the vertebral column, pelvic girdle and hindlimbs in ventral view. ?as astragalus?, ?ca calcaneum?, $\mathrm{cr}$ caudal ribs, $f$ femur, $f i$ fibula, he hemal spines, $i l$ ilium, is ischium, $m t$ metatarsal, $p$ pubis, $p p x$ proximal phalanges, $s r$ sacral ribs, $t i$ tibia. Numbers $1-10$ indicate preserved caudal vertebrae. Scale bar $10 \mathrm{~mm}$

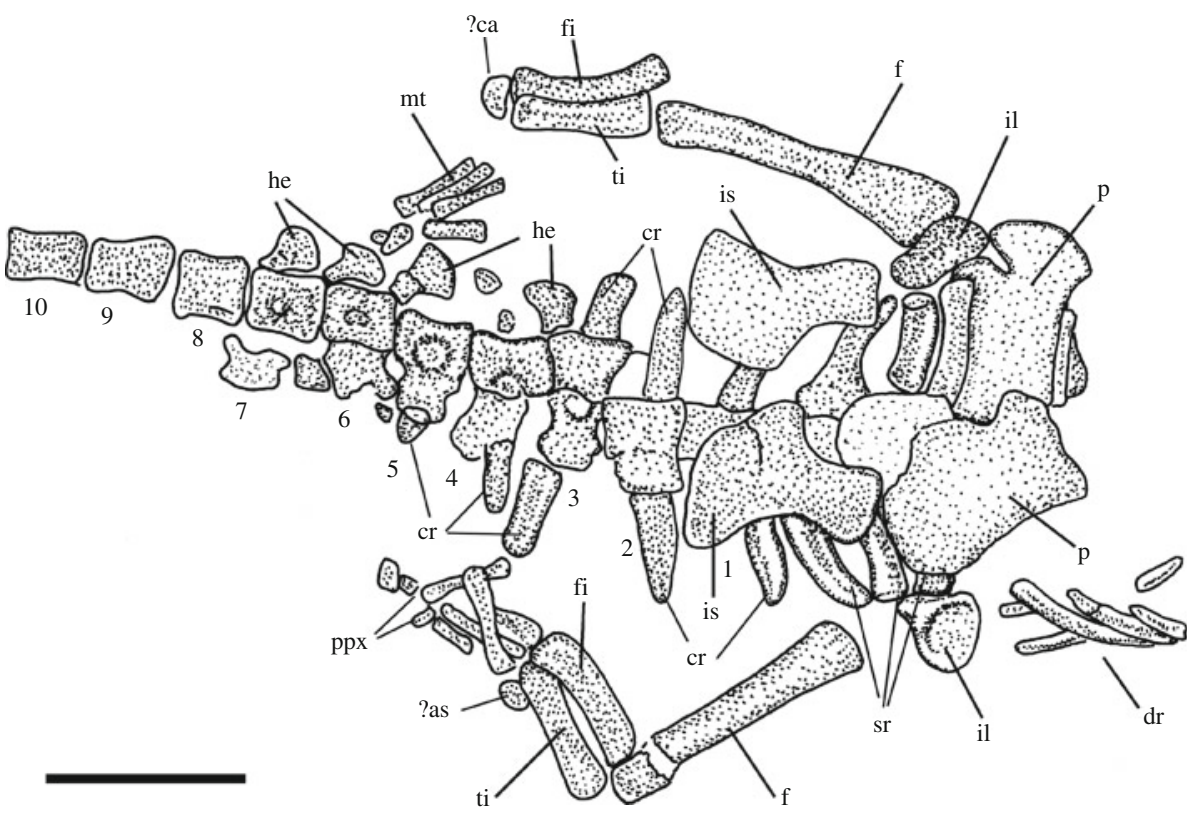

retroarticular is present, the left one being dissociated from other bones. As the quadrates still lie in anatomical connection with both rami of the mandible, the articular areas cannot be observed.

Dentition. Only a few small pointed teeth are preserved on both dentaries along with some scattered teeth of similar size, probably belonging to the right maxilla.

Vertebrae and ribs (Figs. 5, 6, 7). The atlas axis complex along with the subsequent three cervical vertebrae are the only preserved portions of the neck. Their preservation is, however, poor. The atlas apparently bears short ribs, as occurs in N. peyeri and N. edwardsii (Sander 1989). The axis is short and stout, but due to poor preservation, no detailed description can be given. The succeeding cervical vertebrae are nearly twice as long as they are wide and show concave lateral margins giving an hourglass shape to the centrum. At least 17-18 dorsal vertebrae are preserved, mostly in ventrolateral view; the first preserved ones lie close to the medial border of the preserved portion of the right coracoid, suggesting that at least two or three dorsal vertebrae are missing, giving a probable count of 20 dorsal vertebrae. The centra are barrel-shaped and, laterally to each centrum, the lateral edges of the underlying neural arches are visible; the latter are flattened by compression. Four sacral vertebrae are present, partially overlapped by the bones of the pelvic girdle; their centrum is similar to that of the trunk vertebrae. The neural arches and spines are exposed in lateral view, partially overlapped by the centra. The first 10 caudal vertebrae are also preserved in lateral view (Fig. 7); they show the rib articulations shifting gradually from the neural arch to the centrum, so that, from the fifth caudal vertebra on, the transverse process lies on the centrum only. The neural spines of the sacral and first but no coronoid process is visible. A well-developed 
eight caudal vertebrae are well developed and are comparable to those of $N$. peyeri, proportionally higher than in $N$. pusillus, but lower than those of N. edwardsii.

The trunk ribs are single-headed and thickened at the proximal end. The last three trunk ribs have a straight shaft and are much shorter than the preceding ones. A further five caudal vertebrae, possibly the last ones, are present on a separate slab; despite their poor preservation it can be seen that the centra are twice as long as they are deep. Two pairs of sacral ribs can be identified with confidence. They are short, stout and straight, converging on one point to meet the ilium, where they form a well-developed articular surface. Given the disarticulation and overlapping of the pubis and comparing the rib structure of other neusticosaurs, where three short, stout sacral ribs are always present, it is conceivable that the first pair of sacral ribs lies below the disarticulated right pubis, along with the corresponding vertebra. The following pair of ribs are longer, less robust and curved cranially at their distal end, pointing toward the ilium; their shafts distinctly taper distally and only the left rib seems to form a tiny articular surface. This pattern is typical for $N$. peyeri (Sander 1989, p. 609), in which specimens may have four sacral ribs on one side and three on the other. Five pairs of caudal ribs can be observed, slightly displaced from their corresponding vertebrae; they show a tapering distal end and their size decreases abruptly after the fourth one. Caudally to the fifth preserved rib, two other transverse processes are clearly visible on the caudal centra, testifying to the presence of seven caudal ribs on the left side and eight on the right side.

The chevrons of the third to the seventh/eighth caudal vertebrae are preserved; they are small elements, showing the distally expanded shape and rounded ventral margin which is typical of neusticosaurs.

Pectoral and pelvic girdles (Figs. 6, 7). The caudal halves of the coracoids are the only preserved elements of the pectoral girdle so that no description of the shoulder girdle can be given. On the contrary, the pelvic girdle is complete, even though slightly disarticulated and partly crushed. The ilium is a small subtriangular bone with an elongate tip. The pubis is a subrectangular bone, with convex medial and lateral margins and slightly concave anterior and posterior margins. The obturator foramen is slit-like and lies at the posterior margin of the bone, very close to the acetabulum. The ischium bears a flattened and expanded medial portion, a narrow waist and a thickened lateral portion which joins other pelvic bones.

Forelimb (Fig. 6). The left humerus is preserved, and bears a thick proximal end and a wide, flattened distal end. The anterior margin has a nearly straight outline, whereas the posterior one is concave, and a small entepicondylar foramen is present close to the distal end. The proximal head is thick and subtriangular in section, while the distal head is flattened; the distal articular surface is nearly flat with slightly raised margins. Only the distal halves of the radius and of the ulna are preserved, the proximal ones being, however, recognizable by impressions in the matrix. They are both thick, rod-like bones and the radius is longer and somewhat narrower than the ulna. Two carpals, an elongate intermedium and a rounded ulnare are present. Metacarpals and phalanges partially overlap; however, it can be seen that the third metacarpal is slightly longer than the fourth.

Hindlimb (Fig. 7). The femur has a straight narrow shaft and is slightly expanded at both ends. The distal articular surface is nearly flat. The tibia is straight and thicker than the fibula. The latter has a slightly curved shaft with a distinctly concave medial margin. In both the tibia and the fibula, the proximal and distal articular surfaces are nearly straight or faintly convex. The tarsus consists of two rounded elements, a large astragalus and a much smaller calcaneum. Metatarsals are superimposed on each other, precluding any detailed description. Only a few phalanges are preserved, thus rendering a phalangeal count impossible.

\section{Systematic discussion}

The morphological and morphometrical features of specimen MCSN 8076 described above match those of pachypleurosaurs composing the Serpianosaurus-Neusticosaurus clade and rule out ascription to the sister-taxa from the Germanic basin (Anarosaurus and Dactylosaurus) and from the eastern Tethyan faunal province (Hanosaurus and Keichousaurus).

The genus Anarosaurus DAmEs 1890 (Rieppel and Lin 1995; Rieppel 2000) has a spatulate expansion of the tooth crown which is absent in MCSN 8076, a higher dorsal vertebral count (25-26 dorsal vertebrae compared to 20 in MCSN 8076) and a femur which is proportionally more elongated with respect to the trunk (femur vs. standard length ratio: 1.55 in Anarosaurus and 1.01 in MCSN 8076). The genus Dactylosaurus GüRICH 1884 has body proportions similar to those of the pachypleurosaurs of the Serpianosaurus-Neusticosaurus clade; however, specimen MCSN 8076 cannot belong to Dactylosaurus, since the latter was diagnosed (Rieppel and Lin 1995) by means of the presence of an entepicondyle on the humerus distinctly set off from the shaft, at least in sex y (the entepicondyle is not set off from the shaft in MCSN 8076, but this character must be used with caution since it is not possible to assign the specimen to either sex), and of a notch on the preaxial margin of the radius (the margin is straight in MCSN 8076). In addition, Dactylosaurus (Rieppel and Lin 1995; Rieppel 2000) has a conspicuous deltopectoral crest set off from a distinctly waisted diaphysis (in MCSN 8076 the deltopectoral crest is much smaller and the shaft is nearly straight). 
The genus Keichousaurus Young 1958 differs from MCSN 8076 in most diagnostic characters as listed by Rieppel and Lin (1995) and Rieppel (2000): in fact, Keichousaurus shows a skull of a different shape, with a short, blunt rostrum (more elongate in MCSN 8076), only 2-3 sacral vertebrae (the sacral vertebrae count is higher in MCSN 8076), a humerus without entepicondylar foramen and a distinctly wide nothosaur-like ulna (more rod-like in MCSN 8076).

MCSN 8076 clearly differs from Hanosaurus Young 1972 due to the shape of the elements of the pelvic girdle (Rieppel 1998), which in Hanosaurus is characterized by the absence of a thyroid fenestra (present in MCSN 8076), a subcircular pubis (subrectangular in MCSN 8076) and an ischium with articular facets for the ilium and pubis which are separated by a distinct notch which forms part of the obturator foramen (not the case in MCSN 8076).

The small Neusticosaurus toeplischi (NopCsA 1928), whose diagnostic remains are restricted to Ladinian deposits of Austria, bears a distinct difference to MCSN 8076 in that it has a relatively shorter humerus than other pachypleurosaurs nested in the crown-group pachypleurosaurs (Serpianosaurus-Neusticosaurus clade) from the Ladinian (Rieppel and Lin 1995). According to Rieppel (2000), the diagnosis of Neusticosaurus staubi (Kuhn-Schnyder 1959) from the Prosanto Formation (Kuhn-Schnyder 1959; Bürgin et al. 1991) does not allow unequivocal differentiation from other Neusticosaurus species and, within the latter genus, $N$. staubi cannot be distinguished from $N$. pusillus (see further below).

Among the remaining pachypleurosaurs, all occurring in the Monte San Giorgio basin, when comparing MCSN 8076 with specimens of similar size attributed to Serpianosaurs RIEPPEL 1989 (juvenile specimens such as T132, see Rieppel 1989, pp. 71-72), unequivocal differences in proportions appear evident which preclude any attribution to this genus.

Taking into consideration the above, both morphological and morphometrical characters seem consistent with the attribution of specimen MCSN 8076 to Neusticosaurus peyeri. The wedge-shaped skull with a waisted postorbital region which is shorter and wider than the antorbital region rules out $N$. pusillus, which has a narrow skull table with parallel margins (Carroll and Gaskill 1985; Sander 1989; Rieppel and Lin 1995; Rieppel 2000). In addition, the dorsal vertebrae count (probably 20) is lower than in N. pusillus (22-24; Sander 1989, p. 578; Rieppel and Lin 1995, p. 35; Rieppel 2000, p. 53). The neural spines of the last dorsal, the sacral and the first caudal vertebrae are rather low in comparison to those of $N$. edwardsii. According to Sander (1989, p. 602) the number of caudal ribs in Neusticosaurus peyeri is constant at eight (or seven), sometimes only on one side of the body if one of the ribs reaches the ilium; this number is much lower than that of N. edwardsii, which has at least 10-14 caudal ribs (Carroll and Gaskill 1985, p. 371). In addition, in specimen MCSN 8076 the neural arch forms part of the transverse process until the fifth caudal vertebra, as in N. peyeri (Sander 1989, p. 610), whereas it is present only until the third caudal vertebra in N. edwardsii (Carroll and Gaskill 1985, p. 370). The presence of only two ossified carpals is suggestive of $N$. peyeri and $N$. pusillus, in contrast with $N$. edwardsii which has a third carpal (Carroll and Gaskill 1985, p. 375; Rieppel and Lin 1995, p. 35; Rieppel 2000, p. 53), that is easily recognizable (Sander 1989, p. 598). Admittedly, the third carpal in $N$. edwardsii is a tiny element so that its absence in MCSN 8076 could be due to either a preservation bias or a lack of ossification in case of its being a juvenile specimen. However, the ulnare is smaller and roundish (Sander 1989, p. 598), as typically observed in both N. peyeri and N. pusillus (Sander 1989, p. 598), whereas it is relatively elongate in $N$. edwardsii (Carroll and Gaskill 1985, p. 375, fig. 17). In MCSN 8076 the proximal phalanges of digits 2-4 of the pes are distinctly shorter than the corresponding metatarsals (Fig. 7), while they are of comparable length in N. edwardsii (Carroll and Gaskill 1985, p. 348). The body proportions of MCSN 8076 also seem to match the range of variability of $N$. peyeri or $N$. pusillus rather than that of $N$. edwardsii, using the ratios calculated by Sander (1989, p. 631, tab. 9) and Rieppel and Lin (1995, pag. 11, tab. 3) (Table 1). This

Table 1 Comparison of ratios between different length of skeletal elements, calculated for specimen MCSN 8076 and different Neusticosaurus species from Monte San Giorgio, as reported by Sander (1989, p. 631, tab. 9; ratios of both sexes combined)

\begin{tabular}{lllll}
\hline & MCSN 8076 & N. pusillus & N. peyeri & N. edwardsii \\
\hline $\mathrm{h} / \mathrm{f}$ & 1.19 & $0.88-1.15$ & $0.90-1.30$ & $1.24-1.84$ \\
$\mathrm{~h} / \mathrm{stand}$ & 1.20 & $0.95-1.50$ & $0.75-1.25(0.86-1.25)$ & $1.18-1.39$ \\
$\mathrm{~h} / \mathrm{r}$ & 1.92 & $1.70-1.95$ & $1.60-1.90$ & $1.70-2.12$ \\
$\mathrm{r} / \mathrm{stand}$ & 0.63 & $0.50-0.75$ & $0.44-0.71$ & $0.62-0.69$ \\
$\mathrm{f} / \mathrm{stand}$ & 1.01 & $0.97-1.40$ & $0.78-1.06(0.79-1.06)$ & $0.65-0.96$ \\
\hline
\end{tabular}

Only if different from the former, data from Rieppel and Lin (1995, p. 11, tab. 3) are also reported and listed in parentheses

$f$ femur, $h$ humerus, $r$ radius, stand standard (last four presacral vertebrae) 
is true even taking into account its small absolute size, since in the smaller specimens of $N$. edwardsii most body proportions (as reported by Carroll and Gaskill 1985) may to some extent overlap with those of an adult $N$. peyeri, thus rendering them of little use for species identification. However, even in the smallest specimens of $N$. edwardsii the humerus/femur and femur/standard length ratios are different from those of specimens belonging to $N$. peyeri and to $N$. pusillus. The femur/standard length ratio of MCSN 8076 is 1.01 , well within the range of $N$. peyeri (0.78-1.06), while the range for $N$. edwardsii extends from 0.65 to 0.96 , averaging 0.73 in juvenile specimens (specimen 3447 in Carroll and Gaskill 1985), therefore indicating a distinctly shorter femur than in MCSN 8076. $N$. edwardsii itself is also explicitly diagnosed on the basis of its having a relatively shorter femur than other neusticosaurs (Sander 1989, p. 617, 632; Rieppel and Lin 1995, p. 35; Rieppel 2000, p. 53) and the femur is considered to grow isometrically in these taxa (Sander 1989, p. 563). The only $N$. edwardsii specimen which has comparable proportions with MCSN 8076 is a juvenile of very small size with an humerus/femur ratio of 1.13; but this specimen has been regarded as incorrectly classified by O'Keefe and Sander (1999, p. 510) and by O'Keefe et al. (1999, p. 528), since it does not possess the features characterizing the $N$. edwardsii population as a whole (O'Keefe and Sander 1999, fig. 4). Furthermore, this specimen, referred to by Cornalia (1854) as "esemplare minore" ("smaller specimen") and described by the same author as Pachypleura edwardsii, comes from a different locality (Cà del Frate, Varese, Italy), and, to make things even more confusing, from a not reliably identified stratigraphic horizon (Cornalia 1854). Unfortunately, this specimen was designated as the type specimen of Pachypleura edwardsii by Boulenger (1898, p. 7, while no holotype was originally selected by Cornalia 1854), which obviously raises serious taxonomic questions about its correct identity (O'Keefe and Sander 1999). Disregarding the above-mentioned specimen, $N$. edwardsii juveniles of a size comparable to MCSN 8076 (see specimens 3439 and 3447 in Carroll and Gaskill 1985, tab. 3) show a distinctly higher humerus/femur ratio, ranging from 1.45 to 1.60 (MCSN 8076: 1.19).

Carroll and Gaskill (1985) calculated the femur/posterior trunk vertebra ratio; in this respect, MCSN 8076 shows a ratio of 4.2 , thus different from the range of variability reported for $N$. edwardsii (2.6-3.2) and comparable with that of smaller neusticosaurs (Carroll and Gaskill 1985).

In summary, the morphometrical and morphological features described above give, as a whole, reasonable support to the attribution of MCSN 8076 to Neusticosaurus peyeri.

\section{Conclusions}

The attribution of specimen MCSN 8076 to Neusticosaurus peyeri on the basis of both morphological and morphometrical data raises some questions regarding the strict correlation between pachypleurosaurid taxa and fossiliferous horizons in the Monte San Giorgio basin as originally proposed by Sander (1989) and afterwards supported by O'Keefe and Sander (1999). According to these authors, only N. edwardsii, the youngest and largest Neusticosaurus species, ought to occur in the Cassina beds. Further evidence against this assumed sequential temporal appearance is provided by a specimen from the Upper Meride Limestone (likely late Ladinian in age), thus stratigraphically even younger than that described here, and ascribed to Neusticosaurus cf. N. peyeri (MUMSG 134; Renesto and Felber 2007). Admittedly, in that case the attribution was more tentative, since the specimen was preserved only as an impression on the slab, whereas the actual bones were missing, making both measurements and morphological description less reliable. However, if its stratigraphic assignation is correct, MUMSG 134 would be the only instance of a Neusticosaurus occurrence above the Cassina beds and, as such, the youngest pachypleurosaurid recorded in the Monte San Giorgio sequence. Furthermore, additional evidence came to light in 1997 during the 1997-2005 excavations in the Cava superiore beds at the Acqua del Ghiffo site, carried out by the PIMUZ in collaboration with the MCSN. Along with a large collection of specimens attributed to N. peyeri (according to Sander 1989 the only species occurring in this horizon) one specimen was recovered and ascribed to N. edwardsii (MCSN 5624; Heinz Furrer, PIMUZ, personal communication, 2009).

Even though somewhat fragmentary, these recent data would seem to call into question the hypothesis of Sander (1989) and O'Keefe and Sander (1999) which suggested a strictly sequential temporal appearance. The overlapping of $N$. edwardsii and N. peyeri in spatial and temporal distribution would refute the view of a single anagenetic lineage without a branching event separating the different Neusticosaurus species (O'Keefe and Sander 1999), since such a scenario would require a complete lack of species cooccurrence. The above data suggest that, after the appearance of Neusticosaurus pusillus in early Ladinian Cava inferiore beds, two different species co-existed in the Monte San Giorgio basin (or in the Monte San Giorgio subbasin if the Meride Limestone shared the same basin with the Perledo-Varenna Formation), namely, N. peyeri and $N$. edwardsii, at least up to the level of the Cassina beds (Fig. 8). Unfortunately, the subsequent fossil record is as yet largely incomplete, but it suggests a persistence of $N$. peyeri through the central segment of the Upper Meride Limestone (likely late Ladinian in age). No pachypleurosaurids have so 


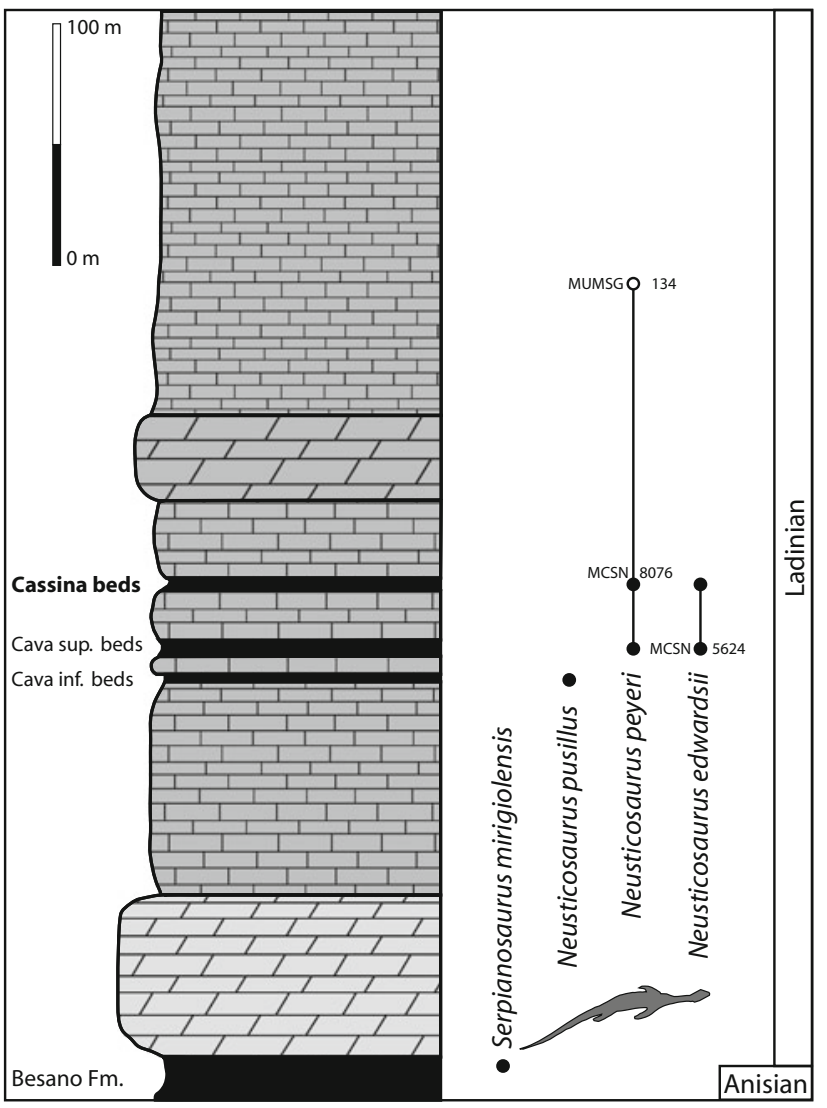

Fig. 8 Stratigraphic distribution of the pachypleurosaurids from Monte San Giorgio on the basis of the recent finds (Renesto and Felber 2007, and this paper). Open circles indicate fragmentary specimens not yet definitively assigned

far been recovered from the Kalkschieferzone. The inferred co-occurrence of $N$. peyeri and $N$. edwardsii may provide evidence of habitat partitioning, based on the marked differences in adult size (up to $550 \mathrm{~mm}$ and up to $1,200 \mathrm{~mm}$ in overall length, respectively, according to Rieppel 2000), as well as in dentition (the tooth count is higher in $N$. edwardsii, which also shows more functional teeth; Sander 1989).

The co-occurence of N. peyeri and N. edwardsii in the same levels implies that the two species indicate possible adaptations toward different size- and/or trophic-related niches rather than representing an anagenetic lineage. Sander's (1989) hypothesis of anagenetic lineage of the Neusticosaurus species of Monte San Giorgio would also have implied a reversal in the height of neural spines, as pointed out by Rieppel (2000, p. 52), as well as in the number of presacral vertebrae. In fact, according to O'Keefe et al. (1999), the mean presacral vertebral count is 38-42 in $N$. pusillus, followed by a decrease to an approximate average of 35 in $N$. peyeri, followed by a new increase to a mean of about 38 in $N$. edwardsii (which corresponds to the ancestral state occurring in Serpianosaurus). Postulating a reversal from $N$. peyeri to $N$. edwardsii would no longer be necessary if the two species co-existed, possibly occupying different niches, as the finding of MCSN 8076 in the Cassina beds suggests.

While the co-occurrence of $N$. peyeri and N. edwardsii may well challenge Sander's (1989) hypothesis of anagenetic lineage among Neusticosaurus species as well as their stratigraphic significance, an in-depth re-evaluation of the evolutionary scenario of Neusticosaurus species would require a thorough revision of the original material in order to either corroborate or reject the signal of cladistic structure among the three species (Rieppel 2000).

Acknowledgments The authors are indebted to Remo Pagani, the owner of the Cassina property, for his enthusiastic interest in the excavations led by the first author, and to the many students and volunteers who helped during the field works for their unconditional commitment. Sergio Rampinelli found the specimen described in this article. Many thanks to Stefano Doninelli (commissione parrocchiale Monte San Giorgio) for kindly making the Adenofora mountain refuge available, and to the municipality of Meride for logistic support. We would also like to thank Heinz Furrer (PIMUZ) for information concerning the specimen from the Acqua del Ghiffo site and for permission to publish data on its identification. The palaeontological preparation was carried out by the first author and Debora Tollardo (MCSN). The manuscript benefited greatly from the remarks and comments of the reviewers Michael Maisch (Tübingen) and Olivier Rieppel (Chicago). Finally, we would like to thank Stephen Smith for English corrections. Financial support was granted by the Dipartimento del territorio del Cantone Ticino (Museo Cantonale di Storia Naturale) and the Swiss Federal Office for the Environment (FOEN).

\section{References}

Boulenger, G. A. (1898). On a nothosaurian reptile from the Trias of Lombardy, apparently referable to Lariosaurus. Transactions of the Zoological Society of London, 14, 1-10.

Brack, P., Rieber, H., Nicora, A., \& Mundil, R. (2005). The Global boundary Stratotype Section and Point (GSSP) of the Ladinian Stage (Middle Triassic) at Bagolino (Southern Alps, Northern Italy) and its implications for the Triassic time scale. Episodes, 28, 233-244.

Brack, P., Rieber, H., \& Urlichs, M. (1999). Pelagic successions in the Southern Alps and their correlation with the Germanic Middle Triassic. In G. H. Bachmann \& I. Lerche (Eds.), Epicontinental Triassic. Zentralblatt für Geologie und Paläontologie (1998) Teil 1 (pp. 853-876). Stuttgart: E. Schweizerbart'sche Verlagsbuchhandlung.

Brusca, C., Gaetani, M., Jadoul, F., \& Viel, G. (1981). Paleogeografia e metallogenesi del Triassico Sudalpino. In P. Omenetto (Ed.), Correlazioni tra paleogeografia e mineralizzazioni. Memorie della Società Geologica Italiana 22 (pp. 65-82). Roma: Società Geologica Italiana.

Bürgin, T., Eichenberger, U., Furrer, H., \& Tschanz, K. (1991). Die Prosanto-Formation - eine fischreiche Fossil-Lagerstätte in der Mitteltrias der Silvretta-Decke (Kanton Graubunden, Schweiz). Eclogae Geologicae Helvetiae, 84, 921-990.

Bürgin, T., Rieppel, O., Sander, P. M., \& Tschanz, K. (1989). The fossils of Monte San Giorgio. Scientific American, 260, 74-81. 
Carroll, R. L., \& Gaskill, P. (1985). The nothosaur Pachypleurosaurus and the origin of plesiosaurs. Philosophical transactions of the Royal Society of London B, 309, 343-393.

Cornalia, E. (1854). Notizie zoologiche sul Pachypleura edwasdsii COR., nuovo sauro acrodonte degli strati triassici di Lombardia. Giornale dell'Istituto Lombardo di Scienze, Lettere ed Arti, 6, $45-56$.

Frauenfelder, A. (1916). Beiträge zur Geologie der Tessiner Kalkalpen. Eclogae Geologicae Helvetiae, 14, 247-367.

Furrer, H. (1995). The Kalkschieferzone (Upper Meride Limestone; Ladinian) near Meride (Canton Ticino, Southern Switzerland) and the evolution of a Middle Triassic intraplatform basin. Eclogae Geologicae Helvetiae, 88, 827-852.

Furrer, H. (2003). Der Monte San Giorgio im Südtessin-vom Berg der Saurier zur Fossil-Lagerstätte internationaler Bedeutung. Neujahrsblatt der Naturforschenden Gesellschaft Zürich, 206, $1-64$.

Furrer, H., Schaltegger, U., Ovtcharova, M., \& Meister, P. (2008). $\mathrm{U}-\mathrm{Pb}$ zircon age of volcaniclastic layers in Middle Triassic platform carbonates of the Austroalpine Silvretta nappe (Switzerland). Swiss Journal of Geosciences, 101, 595-603.

Hellmann, K. N., \& Lippolt, H. J. (1981). Calibration of the Middle Triassic Time Scale by conventional $\mathrm{K}-\mathrm{Ar}$ and ${ }^{40} \mathrm{Ar} /{ }^{39} \mathrm{Ar}$ dating of alkali feldspars. Journal of Geophysics, 50, 73-88.

Holmes, R., Chen, Y.-N., \& Wu X.-C. (2008). New information on the skull of Keichousaurus hui (Reptilia: Sauropterygia) with comments on sauropterygian interrelationships. Journal of Vertebrate Paleontology, 28, 76-84.

Kuhn-Schnyder, E. (1959). Ein neuer Pachypleurosaur von der Stulseralp bei Bergün (Kt. Graubunden, Schweiz). Eclogae Geologicae Helvetiae, 52, 639-658.

Kuhn-Schnyder, E. (1974). Die Triasfauna der Tessiner Kalkalpen. Neujahrsblatt der Naturforschenden Gesellschaft Zürich, 176, $1-119$.

Kuhn-Schnyder, E. (1994). Bemerkungen über Pachypleurosaurier aus der Mitteltrias des Monte San Giorgio, Schweiz. Eclogae Geologicae Helvetiae, 87, 1023-1027.

Mostler, H. (1993). Das Germanische Muschelkalkbecken und seine Beziehungen zum tethyalen Muschelmeer. In H. Hagdorn \& A. Seilacher (Eds.), Muschelkalk Schöntaler symposium 1991 (pp. 11-14). Korb: Goldschneck Verlag.

Mundil, R., Pálfy, J., Renne, P. R., \& Brack, P. (2010). The Triassic timescale: New constraints and a review of geochronological data. In S. G. Lucas (Ed.), The Triassic timescale. Special Publications of the Geological Society of London, 334, 41-60.

O’Keefe, R. F., Rieppel, O., \& Sander, M. (1999). Shape disassociation and inferred heterochrony in a clade of pachypleurosaurs (Reptilia, Sauropterygia). Palaeobiology, 25, 504-517.

O'Keefe, R. F., \& Sander, M. (1999). Paleontological paradigms and inferences of phylogenetic pattern: A case study. Paleobiology, $25,518-533$.

Picotti, V., Capozzi, R., Bertozzi, G., Mosca, F., Sitta, A., \& Tornaghi, M. (2007). The Miocene petroleum system of the Northern Apennines in the central Po Plain (Italy). In O. Lacombe, et al. (Eds.), Thrust belts and foreland basins. From fold kinematics to hydrocarbon systems (pp. 117-131). Heidelberg: Springer.

Renesto, S., \& Felber, M. (2007). Un Pachipleurosauride dai livelli centrali del Calcare di Meride in Canton Ticino (Svizzera). Geologia Insubrica, 10, 9-12.

Rieppel, O. (1989). A new pachypleurosaur (Reptilia: Sauropterygia) from the Middle Triassic of Monte San Giorgio, Switzerland. Philosophical transactions of the Royal Society of London B, $323,1-73$.

Rieppel, O. (1998). The systematic status of Hanosaurus hupehensis (Reptilia, Sauropterygia) from the Triassic of China. Journal of Vertebrate Paleontology, 18, 545-557.

Rieppel, O. (2000). Sauropterygia I. Placodontia, Pachypleurosauria, Nothosauroidea, Pistosauroidea. In P. Wellnhofer (Ed.), Handbuch der Paläoherpetologielencyclopedia of paleoherpetology, Teil 12A. München: Pfeil.

Rieppel, O. (2010). Triassic marine reptiles (Sauropterygia, Protorosauria, Thalattosauria) from the eastern and western Tethyan faunal provinces. In International symposium on Triassic and later marine vertebrate faunas. Conference abstract book, Beijing, p. 72 .

Rieppel, O., \& Hagdorn, H. (1997). Paleobiogeography of Middle Triassic Sauropterygia in Central and Western Europe. In J. M. Callaway \& E. L. Nicholls (Eds.), Ancient marine reptiles (pp. 121-144). San Diego: Academic Press.

Rieppel, O., \& Lin, K. (1995). Pachypleurosaurs (Reptilia: Sauropterygia) from the Lower Muschelkalk, and a review of the Pachypleurosauroidea. Fieldiana (Geology), n.s., 32, 1-44.

Sander, M. P. (1989). The pachypleurosaurids (Reptilia: Nothosauria) from the Middle Triassic of Monte San Giorgio (Switzerland) with the description of a new species. Philosophical Transactions of the Royal Society of London B, 325, 561-670.

Scheuring, B. W. (1978). Mikrofloren aus den Meridekalken des Mte. San Giorgio (Kanton Tessin). Schweizerische Paläontologische Abhandlungen, 100, 1-205.

Sommaruga, A., Hochuli, P. A., \& Mosar, J. (1997). The Middle Triassic (Anisian) conglomerates from Capo San Martino, South of Lugano-Paradiso (Southern Alps, Switzerland). Geologia Insubrica, 2, 1-14.

Stockar, R. (2010). Facies, depositional environment, and palaeoecology of the Middle Triassic Cassina beds (Meride Limestone, Monte San Giorgio, Switzerland). Swiss Journal of Geosciences, 103, 101-119.

Wirz, A. (1945). Die Triasfauna der Tessiner Kalkalpen. XV. Beiträge zur Kenntnis des Ladinikums im Gebiete des Monte San Giorgio. Schweizerische Paläontologische Abhandlungen, 65, 1-84.

Zangerl, R. (1935). Die Triasfauna der Tessiner Kalkalpen. IX. Pachypleurosaurus edwardsi Cornalia sp. Osteologie-Variationsbreite-Biologie. Abhandlungen der Schweizerischen Paläontologischen Gesellschaft, 56, 1-80.

Zorn, H. (1971). Paläontologische, stratigraphische und sedimentologische Untersuchungen des Salvatoredolomits (Mitteltrias) der Tessiner Kalkalpen. Schweizerische Paläontologische Abhandlungen, 91, 1-90. 